\title{
Assessment of the Nutritional Status on the First-year Students Living in Student Dormitory, Gorno-Altaisk State University, Russia
}

\section{Elena Anatolievna Chanchaeva ${ }^{1}$, Kruglikova Ekaterina Vasilievna ${ }^{1}$, Sergey Sergeevich Sidorov ${ }^{1}$, Alexey Dmitrievich Gerasev ${ }^{2}$ and Roman Idelevich Aizman ${ }^{2,3 *}$}

${ }^{1}$ Department of Physical Education and Sports, Physiology and Life Safety, Gorno-Altaisk State University, Gorno-Altaysk, Russia

${ }^{2}$ Department of Anatomy, Physiology and Life Safety, Novosibirsk State Pedagogical University, Novosibirsk, Russia

${ }^{3}$ Novosibirsk Scientific Research Institute of Hygiene, Novosibirsk, Russia

*Corresponding Author: Roman Idelevich Aizman, Department of Anatomy, Physiology and Life Safety, Novosibirsk State Pedagogical University, Novosibirsk, Russia.
Received: February 23, 2021

Published: March 23, 2021

(C) All rights are reserved by Roman

Idelevich Aizman., et al.

\begin{abstract}
The lack of skills in budgeting and saving expenses and organizing healthy meals is one of the reasons for the unbalanced nutrition of students living in the university dormitory. The assessment of the actual nutrition of first-year students living in student dormitory of Gorno-Altaisk State University was carried out. The students diet is characterized by a lack of calories, fats, including polyunsaturated fatty acids, and an insufficient intake of carbohydrates, including dietary fiber. This deficiency is more pronounced in girls who also have a protein intake deficit, especially of animal origin. It is necessary to include in the work of the curators of the first-year students tips on planning financial costs and organizing a healthy diet.
\end{abstract}

Keywords: First-year Students; Healthy Eating; University Dormitory; Adaptation

\section{Abbreviations}

GASU: Gorno-Altaisk State University; SFA: Saturated Fatty Acids; PUFA: Polyunsaturated Fatty Acids.

\section{Introduction}

The lifestyle of first-year students is changing in connection with the transition to independent life, they must show self-organization, discipline and responsibility [1]. In social life, students must be able to plan expenses, while determining the costs of basic necessities (expenses for housing rent, travel, full meals, subjects for training, etc.) [2]. In many foreign countries, beginning students are offered the practice of calculating household expenses through an online calculator system, which is presented on the websites of educational institutions. Also, the practice of tutoring to attract undergraduate and graduate students to curatorial activities shows high efficiency [3]. Students-mentors pass on the experience of social adaptation to the educational environment to newcomers. In Russian universities, these issues are not given due attention in the educational program.
The results of numerous studies show a general pattern of unbalanced nutrition of students in terms of the ratio of saturated and polyunsaturated fatty acids, insufficient consumption of dietary fiber, lack of full-fledged proteins and excessive consumption of simple carbohydrates $[4,5]$. $20-40 \%$ of Russian students show signs of severe hypovitaminosis [6], especially calciferol, which is deficient not only due to its deficiency in the diet, but also due to geographical, climatic and seasonal factors $[7,8]$. In the body of students, there is an excess of sodium and a lack of magnesium, potassium and iron, which is due to both the composition of the food consumed and the characteristics of the accumulation and excretion of these ions [5].

One of the reasons for the unhealthy diet of students is the lack of methodological tools for the curators of the first courses.

The purpose of the study was to evaluate the actual nutrition of the first-year students who are adapting to living in a hostel. 


\section{Materials and Methods}

The study was conducted on the basis of student dormitory of Gorno-Altaisk State University (GASU). Methods of cross-sections and random selection of respondents were used. 60 students aged 18-19 years-old of both genders ( 30 boys and 30 girls) living in the hostel were examined, which amounted to $75 \%$ of the total number of first-year students. The students gave the written consent to participate in the study. The actual nutrition of students was assessed during the period of adaptation to living in a hostel by the questionnaire-weight method. A preliminary survey was conducted to obtain approximate information about the diet and financial costs of students.

\section{Questionnaire}

- Family, first name, patronymic

- Year of birth

- Faculty, group

- What financial resources do you have on average per month?

- How much money have you spent on food in the last two weeks and a month?
- Do you always eat at certain hours, or do you eat without a system (when you have to)?

- How many times a day do you eat hot food?

- What does breakfast usually consist of (specify what foods and in what quantity)?

- Where do you eat during educationl hours? (dining room, snack bar, closest to the University the power point, bring food with you)

- What does dinner usually consist of (specify what products and in what quantity)?

- Describe what you ate during the previous day?

Further, this method was supplemented with a weight method, the observation period of the survey-weight method was one week. To determine the amount of food used for food, the capacity of dishes and the weight of food products were evaluated, and information about nutrition during the day was entered in the "Daily Diet" cards (Table 1).

\begin{tabular}{|c|c|l|l|l|l|l|l|l|l|}
\hline Power mode & Dish & Weight, g & Protein, g & Animals protein, g & Fats, g & PUFA, g & Carbohydrates, g & Dietary fiber, g & Kcal \\
\hline \multicolumn{7}{|c|}{ Day 1 } & & \\
\hline Breakfast & & & & & & & \\
\hline Dinner & & & & & & & & \\
\hline Supper & & & & & & & & \\
\hline Total, per day & & & & & & & & \\
\hline Total, 7 days & & & & & & & & & \\
\hline
\end{tabular}

Table 1: Table for evaluating the food regime by day.

Based on the data obtained, the daily intake of proteins (including animal proteins), fats (saturated fatty acids (SFA), polyunsaturated fatty acids (PUFA), and carbohydrates (simple and complex) was determined using the tables "Chemical composition of food products" [9]. Statistical processing of the results of the study was carried out by calculating the arithmetic mean (M), the error of the arithmetic mean ( $\mathrm{m}$ ), and presenting it as $\mathrm{M} \pm \mathrm{m}$. The differences between the groups were evaluated using the Mann-Whitney Utest for independent samples, and the results were considered reliable at $\mathrm{p} \leq 0.05$.

\section{Results}

When assessing the actual nutrition of students, the recommended indicators were taken into account. It was found that the average daily energy consumption of students is significantly lower than the recommended values, especially for girls (Table 2). Thus, the recommended number of calories is $2200-2800 \mathrm{kcal}$, while for girls this figure was $1554 \mathrm{kcal} /$ day, for boys-2375 kcal/ day. Unlike girls, young men consumed protein, including animal protein, in sufficient quantities. At the same time, insufficient fat intake in general and PUFA in particular was observed in all students, regardless of gender, as well as insufficient carbohydrate intake, especially in girls.

In general, the ratio of proteins, fats and carbohydrates among the surveyed students was as follows: boys - 1,2:1:5, girls - 1:1:4.7, which roughly corresponds to the recommended ratio of 1:1:5. The average values of the daily energy expenditure at the expense of individual nutrients was also consistent with the expected values, as the girls and boys (Table 3). 
03

\begin{tabular}{|c|c|c|c|}
\hline \multicolumn{2}{|c|}{ Regulatory indicators [13] } & Boys & Girls \\
\hline \multirow{2}{*}{$\begin{array}{l}\text { Proteins, } \\
\text { g/day }\end{array}$} & the total number & $80,6 \pm 3,9$ & $53,5 \pm 2,4$ \\
\hline & $\begin{array}{c}\text { including animals } \\
(50 \% \text { of the total amount of proteins })\end{array}$ & $\begin{array}{c}40,2 \pm 3,1 \\
(50 \%)\end{array}$ & $\begin{array}{c}21,4 \pm 1,5 \\
(40 \%)\end{array}$ \\
\hline \multirow{2}{*}{$\begin{array}{l}\text { Fats, } \\
\text { g/day }\end{array}$} & the total number & $65,5 \pm 3,1$ & $50,3 \pm 3,5$ \\
\hline & $\begin{array}{l}\text { including polyunsaturated fatty acids } \\
(6-10 \% \text { of the daily energy) }\end{array}$ & $\begin{array}{c}7,5 \pm 0,5 \\
(2,9 \%)\end{array}$ & $\begin{array}{c}3,5 \pm 0,2 \\
(2,1 \%)\end{array}$ \\
\hline \multirow{2}{*}{$\begin{array}{l}\text { Carbohydrates, } \\
\text { g/day }\end{array}$} & the total number & $340 \pm 11,9$ & $211,2 \pm 11,3$ \\
\hline & including dietary fiber ( $20 \mathrm{~g} /$ day $)$ & $15,6 \pm 1,3$ & $11,3 \pm 0,6$ \\
\hline & Kcal/day & $2375,5 \pm 79,6$ & $1554,7 \pm 69,9$ \\
\hline \multicolumn{4}{|c|}{ Differences between boys and girls are significant $(\mathrm{p}<0,01)$. } \\
\hline \multicolumn{4}{|c|}{ The normal values are presented in the parentheses } \\
\hline
\end{tabular}

Table 2: Macronutrient composition and caloric content of the daily diet of students living in the GASU dormitory.

\begin{tabular}{|c|c|c|c|c|c|}
\hline The coefficient of physical activity & Gender & Protein, $\mathbf{g}$ & Fats, g & Carbohydrates, g \\
\hline \multirow{2}{*}{$1,4-1,6$} & Man & $72-80$ & $81-93$ & $358-411$ \\
\cline { 2 - 5 } & Woman & $61-66$ & $67-73$ & $289-318$ \\
\hline
\end{tabular}

Table 3: The daily requirement of the population of 18-29 years in proteins, fats, carbohydrates and calories.

\section{Discussion}

According to the survey, first-year students at the time of the survey were mainly engaged in the learning process, which allowed us to attribute this contingent to the population groups with a coefficient of physical activity in the range of 1.4-1.6 conventional units. The needs of this category of the population in proteins, fats and carbohydrates are presented in table 3 [10].

Thus, the actual food freshmen living in the dormitory, is characterized by the lack consumed Kcal, fats, including polyunsaturated fatty acids, inadequate intake of carbohydrates, including dietary fiber. This deficiency is more pronounced in girls, who also have a deficit in the consumption of proteins, especially of animal origin.

One of the main problems of socialization of first-year students to independent life is the inability to plan and save expenses. In this regard, there is a problem of lack of financial resources for proper nutrition.

The results of numerous studies indicate a general pattern of unbalanced nutrition of the modern generation in terms of the ratio of saturated and polyunsaturated fatty acids, insufficient consumption of complex carbohydrates, in particular dietary fiber, lack of full-fledged proteins and excessive consumption of simple carbohydrates $[5,11]$. Many studies show that students lack the necessary knowledge about a balanced diet and how to organize a healthy diet $[11,12]$.
In the system of educational work of Russian universities, it is necessary to introduce the practice of teaching first-year students budget financial expenses using an online calculator that prescribes priority expenses, helps to determine the financial minimum for the cost of a full meal.

\section{Conclusion}

The lack of skills in budgeting and saving expenses, organizing healthy meals is one of the reasons for the unbalanced nutrition of students living in the hostel. It is necessary to include in the work of the curators of the first courses advice on planning financial expenses and organizing a healthy diet.

\section{Conflict of Interest}

The Authors declares that there is no conflict of interest.

\section{Bibliography}

1. OrlovA., et al. "A study of first-year students' adaptation difficulties as the basis to promote their personal development in university education". Psychology in Russia 11.1 (2018): 171184.

2. BoichenkoA., et al. "Financial capability among Moscow and Berlin students". Vestnik MIRBIS 15.3 (2018): 159-176.

3. Arco-TiradoJ., et al. "Evidence-based peer-tutoring program to improve students' performance at the university". Studies in Higher Education 45 (2020): 2190-2202. 
4. Gritsina0., et al. "Hygienic conditions of supplementary educational organizations and health of children". Human Ecology 3 (2020): 16-22.

5. Gorbatkova E., et al. "Hygienic evolution of nutritional in students of higher educational institutions". Hygiene and Sanitation 98.5 (2019): 540-545.

6. Vilms E., et al. "Analysis of the causes of the epidemic of hypovitaminosis and microelementosis in the Russian Federation". Nutrition Issues 85.S2 (2016): 88.

7. Sosa Henríquez Manuel and M Jesús Gómez de Tejada Romero. "Cholecalciferol or Calcifediol in the Management of Vitamin D Deficiency”. Nutrients 12.6 (2020): 1617.

8. Amrein Karin., et al. "Vitamin D deficiency 2.0: an update on the current status worldwide". European Journal of Clinical Nutrition 74.11 (2020): 1498-1513.

9. Skurikhin IM and Tutelia VA. "Tables of chemical composition and calorie content of Russian food products". Moscow: DeLiprint, (2000).

10. Rospotrebnadzor Federal Center for Hygiene and Epidemiology of Rospotrebnadzor. Norms of physiological needs for energy and food substances for various groups of the population of the Russian Federation: methodological recommendations. Moscow: Federal Center for Hygiene and Epidemiology of Rospotrebnadzor (2009).

11. Zhamsaranova S., et al. "The influence of the nature of nutrition on the antioxidant status of undergraduate students". Science for Education Today 9.1 (2019): 226-248.

12. SprakeE., et al. "Dietary patterns of university students in the UK: a cross-sectional study”. Nutrition Journal 17 (2018): 90.

13. Rospotrebnadzor, Federal Center for Hygiene and Epidemiology of Rospotrebnadzor. Norms of physiological needs for energy and food substances for various groups of the population of the Russian Federation: methodological recommendations. Moscow: Federal Center for Hygiene and Epidemiology of Rospotrebnadzor (2009).

\section{Assets from publication with us}

- Prompt Acknowledgement after receiving the article

- Thorough Double blinded peer review

- Rapid Publication

- Issue of Publication Certificate

- High visibility of your Published work

Website: https://www.actascientific.com/

Submit Article: https://www.actascientific.com/submission.php Email us: editor@actascientific.com

Contact us: +919182824667 